\title{
Groundwater mixing and geochemical assessment of low-enthalpy resources in the geothermal field of southwestern Tunisia
}

\author{
Houda Besser ${ }^{1,2} \cdot$ Naziha Mokadem $^{2,3} \cdot$ Belgacem Redhaounia $^{2,4} \cdot$ Riheb Hadji2, $^{2,5}$ Amor Hamad ${ }^{1,2,6}$. \\ Younes Hamed ${ }^{1,2,7}$
}

Received: 20 June 2017 / Accepted: 5 February 2018 / Published online: 21 February 2018

(c) The Author(s) 2018. This article is an open access publication

\begin{abstract}
In southern Tunisia, the lack of permanent surface water, associated with drought conditions, leads to an endless abstraction from the limited low renewable multi-layered aquifer system of Système Aquifère du Sahara Septentrional containing two principal aquifers, the complex terminal and the Continental Intercalaire (CI) multi-layered systems. The deepest aquifer embodies the low-enthalpy thermal resources of Southern Tunisia. The thermo-mineral surface manifestations of the conductively heated waters reveal the complexity of the geotectonic history of the region and create oases systems in net contrast to the desertic landscape of the Chotts region. As agriculture constitutes the principal economic activity in the studied area and as it is currently threatened by thermal water quality degradation, the present hydrogeological investigation aims for a characterization of the $\mathrm{CI}$ thermal resources on the basis of a critical quality evaluation. Thus, different geothermometry approaches have been applied to characterize the low-enthalpy thermal field showing a temperature ranging from 27 to $72{ }^{\circ} \mathrm{C}$. The application of cations geothermometers owns to different temperature estimations ranging from 28 to $202^{\circ} \mathrm{C}$. Based on $\mathrm{Na}^{+}-\mathrm{Mg}^{2+}-\mathrm{K}^{+}, \mathrm{K}^{+}-\mathrm{Mg}^{2+}-\mathrm{Ca}^{2+}$ and $\mathrm{HCO}_{3}{ }^{-}-\mathrm{Cl}^{-}-\mathrm{SO}_{4}{ }^{2-}$ geoindicators, the $\mathrm{CI}$ thermal resources refer to immature waters characterized by MI varying from -0.5 to 0.19 . The assessment of groundwater chemical composition based on a Durov diagram proves that $\mathrm{CI}$ thermal water is governed by mixing between different water bodies with relative abundance of $\mathrm{Na}^{+}$, $\mathrm{Cl}^{-}$, and $\mathrm{SO}_{4}{ }^{2-}$ elements. According to D'Amore genetic diagram and meteoric genesis indices, the analyzed groundwater derived from deep circulation in sandy formations. The water quality can change along fluid migration pathways expressed by scattered isotopic and chemical data and a number of mixing ratios. Most changes in the background CI composition result from continuous pumping that modifies natural flows and increase quality degradation.
\end{abstract}

Keywords Continental Intercalaire $\cdot$ Geothermometers $\cdot$ Mixing $\cdot$ Geoindicators $\cdot$ MI $\cdot$ Southwestern Tunisia

Houda Besser

besserhouda@gmail.com

Naziha Mokadem

nazouhmoka@gmail.com

Belgacem Redhaounia

belgacem.redhaounia@yahoo.fr

Riheb Hadji

hadjirihab@yahoo.fr

Amor Hamad

hsamir2001@gmail.com

Younes Hamed

hamed_younes@yahoo.fr

1 Research Unit of Geosystems, Georesources and Geoenvironnements (U3G), Department of Earth Sciences, Faculty of Sciences of Gabes, University of Gabes, Zrig, 6072 Gabès, Tunisia
2 International Association of Water Resources in the Southern Mediterranean Basin, Faculty of Sciences of Gafsa, Gafsa, Tunisia

3 Laboratory of Water, Energy and Environment (L3E), ENI-Sfax, Gabès, Tunisia

4 Water Researches and Technologies Center Borj-Cedria (CERTE), BP 273 Soliman, 8020 Borj Cedria, Tunisia

5 Department of Earth Sciences, Institute of Architecture and Earth Sciences, Farhat Abbas University, 19000 Sétif, Algeria

6 Water and Environment Laboratory, Tebessa University, Tebessa, Algeria

7 Department of Earth Sciences, Faculty of Sciences of Gafsa, University of Gafsa, Gafsa, Tunisia 


\section{Introduction}

The past decades have witnessed increasing interest in geothermal resources of Système Aquifère du Sahara Septentrional (SASS) aquifers in Chotts Basin, as they constitute promising natural resources of renewable energy to meet the growing demand and to maintain environmental safety standards (Vimmerstedt 1998; Boyce and Fitzsimmons 2003). Generally, the geothermal systems are studied in regards to the diversification of their utilization (Arnorsson et al. 2000; Dotsika et al. 2006) and to the usefulness of temperature variations as a tracer to identify groundwater movement, origin, mixing of different water bodies, and the quantifying process governing geothermal fluid chemistry (Ben Dhia and Bouri 1995; Boyce and Fitzsimmons 2003; Deon et al. 2015).

The hydrothermal resources investigation is based on various thermal surface manifestations expressed principally by hot springs, which constitute key identification parameters of geothermal activities before any geophysical, geological, and geochemical reconnaissance (Deon et al. 2015). Otherwise, a successful exploration of these promising natural resources of renewable energy depends on an estimation of thermal fluid temperature. Thus, the apparent inconsistency of aquifer depth and waters temperature leads to the development of a variety of statistic and chemical tools and modeling parameters of estimation of hydrothermal system temperature (geothermometers, geo-indicators, etc.) based on geochemical and isotopic data and depending on hydrogeological and tectonic conditions of thermal fields (Fournier and Truesdell 1973; Fournier 1977; Giggenbach 1988; Can 2002).

The geothermometers are based on specific temperature-dependant equilibrium reactions and they are represented by three different categories: cation, isotope, and gas geothermometers applied to both natural springs discharge (surface manifestations) and well fluids. The theoretical basis of geothermometry methods was first proposed by Reed and Spycher (1984), and then a number of works revised and developed a variety of statistic and chemical tools function of different geological, structural, and hydrogeological conditions. Although their wide application, the geothermometers reliability to lowenthalpy systems reservoir temperature estimation still limited and controversial (Porowski and Dowgiallo 2009).

In Tunisia, Ben Dhia and Bouri (1995) identified five geothermal provinces depending on geological and structural characteristics and function of the distribution of hot springs. As matter of fact, it is a distinction between the northeastern part hosted in volcanic rocks and the sedimentary basins in the other provinces (Stefansson 1985; Makni et al. 2012; Ben Brahim et al. 2013). This study was conducted in the southern geothermal province, characterized by normal conductive heat flow in the crust (Ben Dhia and Bouri 1995). The geothermal resources are attributed to the Continental Intercalaire (CI) multi-layered aquifer system widely used in agriculture activities. Thus, this hydro-geochemical investigation aims to provide an equivocal estimation of CI thermal water temperature using classical cation geothermometers and to assess the dynamic chemical behavior of CI groundwater.

\section{Study area}

\section{Geological and climatic settings}

This study was conducted in southwestern Tunisia. The region of interest lies within the coordinates $7^{\circ} 30^{\prime}-10^{\circ} \mathrm{E}$ and $33^{\circ}-34^{\circ} 30^{\prime} \mathrm{N}$ (Fig. 1). The north is occupied by Chotts salt lakes and the south by the Great Oriental Erg sandy dunes. It is dominated by temperate continental arid climate expressed by elevated temperature, scanty precipitations, and high evapotranspiration rates. A number of indices and indicators are commonly used to characterize climate variability (dryness and wetness) and to evaluate aridity status (De Martonne 1926; Thornthwaite 1948; UNESCO 1979). For Chotts Basin, the UNESCO, De Martonne, and the Thornwhite aridity indices (De Martonne 1926; Thornthwaite 1948; UNESCO 1979) are calculated according to Eqs. $(1,2,3 a-3 c)$ :

$A I=P / E T_{\mathrm{p}}$, where $E T_{\mathrm{p}}$ is calculated using Penman (1948) formula;

$\mathrm{DM}_{1}=P /(T+10)$,

with $P$ representing the annual precipitation sum $(\mathrm{mm})$ and $T$ an the annual mean air temperature $\left({ }^{\circ} \mathrm{C}\right)$;

$I_{\mathrm{h}}=100 \mathrm{~s} / \mathrm{n}$,

$I_{\mathrm{a}}=100 \mathrm{~d} / \mathrm{n}$,

with $s$ representing the water surplus obtained by the sum of monthly difference of $P$ and $E T_{\mathrm{p}}(\mathrm{cm})$ when $P>E T_{\mathrm{p}}$ and $d$ the water deficiency obtained by the sum of monthly difference of $E T_{\mathrm{p}}$ and $P(\mathrm{~cm})$ when $P<E T_{\mathrm{p}} ; n$ is the sum of surplus water months or deficiency water months; $I_{\mathrm{m}}$ is then defined by:

$I_{\mathrm{m}}=I_{\mathrm{h}}-0.6 I_{\mathrm{a}}$.

Based on the collected weather and climate data (Ferchichi 1996; CRDA 2010, 2015), the calculated aridity indices indicate arid, dry, and arid classifications for the studied region, respectively, with mean values of $0.05,0.3$, and 


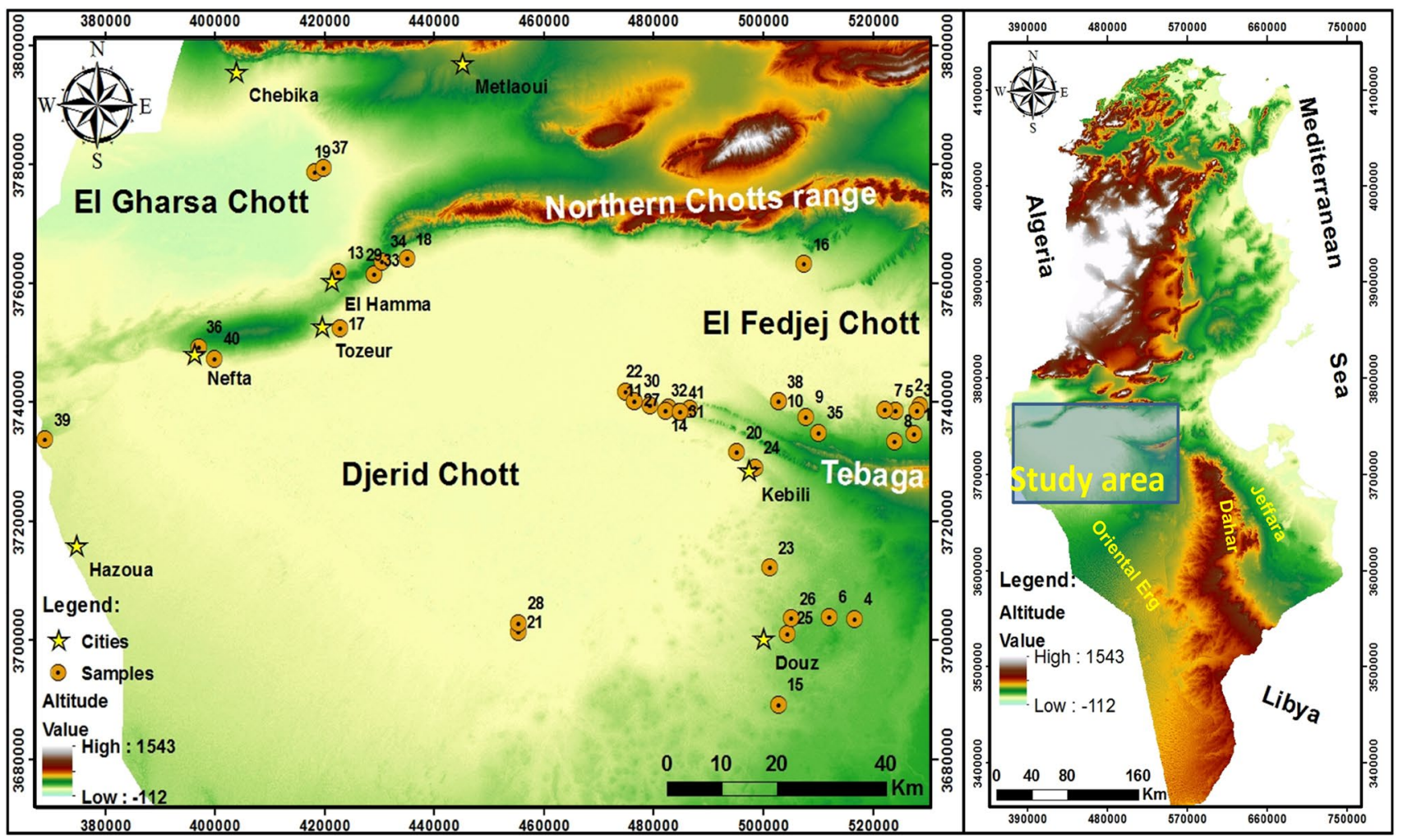

Fig. 1 Location of the study area

- 54.84 for UNESCO, Martonne, and the Thornwhite criteria. Due to the lack of permanent water and the hard climate conditions, farmers depend on groundwater resources to maintain humidity in the oases system.

From a geological point of view, the preserved sedimentary sequence in the study area for both outcrops and the subsurface series is dominated by Mesozoic deposits emphasizing the tectonic control and the importance of subsidence rates at these times. The Jurassic sequence is dominated by carbonates units relative to the equivalent Nara Formation. The Lower Cretaceous is characterized by a mega-sequence of continental material showing a subsequent lateral variation of facies. The Upper Cretaceous series are attributed to a transgressive cycle made essentially by carbonates formations admitting frequent intercalations of sandy, clayey, and marl units. The sedimentary series are lacking from the Upper Cretaceous to early Tertiary related to the uplift of Chotts Basin at these times. Thus, the Neogene and Quaternary continental series unconformably overlay the old deposits of the Late Cretaceous.

Tectonically, the study area constitutes a transition zone between the Saharian platform in the south and the Southern Atlas in the north. Hence, it is characterized by the variety of morpho-structural entities; salt lake depressions, Chotts fold belt separated by El Fedjej depocenter referring to the most external structure of the Atlassic domain, etc. (Zargouni
1985; Bouaziz et al. 2002; Zouaghi et al. 2011). The principal tectonic features are represented by $\mathrm{E}-\mathrm{W}$ normal Chotts fault, NW-SE Gafsa strike slip, and E-W structure of Tozeur uplift (Hlaeim 1999; Lazzez et al. 2008).

\section{Hydrogeological setting}

The study area is characterized by different water-bearing strata laterally and vertically interconnected, differentiated in three main reservoirs; the shallowest is logged in the MPQ formations and the alluvial fillings. Its recharge is attributed to heavy rainfall events, irrigation water return, and leakage from deep aquifers of SASS system. The latter is composed of two multi-layered aquifers: the complex terminal (CT) logged in Upper Cretaceous-Tertiary sediments and the CI hosted in Lower Cretaceous series. The SASS shows a subsequent lateral variation of thickness and lithology. The different flow directions converge to the Chotts throw and to the Gulf of Gabes. The recharge of these waters is mainly attributed and the humid period of the Holocene-Pleistocene (Hamed et al. 2014; Mokadem et al. 2016).

The exploitation of SASS had used to depend on numerous thermo-mineral surface occurrences in southern Tunisia attributed to the CI aquifer and characterized by several water horizons with strong artesian pressure (5-25 bars) and high temperature reaching $75^{\circ} \mathrm{C}$ (Edmunds et al. 1997; 
Fourré et al. 2011; Hamed et al. 2013). Because of the lack of volcanic sources, the high temperatures must be associated with vertical water movements (Ben Dhia 1983; Ben Dhia and Bouri 1995; Ben Brahim et al. 2013). The geothermal potential of the $\mathrm{CI}$ is estimated to be $1000 \mathrm{l} / \mathrm{s}$ (ERESS 1972). It is characterized by highly mineralized water showing a salinity of 3-5 g/l and dominated by $\mathrm{Na}^{+}, \mathrm{Cl}^{-}$, and $\mathrm{SO}_{4}{ }^{2-}$ ions (Edmunds et al. 1997; Hamed et al. 2013; Mokadem et al. 2016). The natural discharge of these aquifers had used to be sufficient resources for agriculture activities and human consumption. The growing population associated with increasing economic pressure leads to an overdraft of the hydrogeological system owing to quasi-extinction of springs and pumping generalization.

The utilization of low-enthalpy CI resources is limited to direct application: heating greenhouses and irrigation of oases systems (80\%). The agriculture activities are constituted by three layers of cultivation: palm trees, fruit trees, and vegetables (Ben Mohamed 2015). Oases systems remain the main use of the irrigated area, as it sustains the socioeconomic pressure of the region and has the highest added value in the export sector. Additionally, as the groundwater geothermal resources are used in heating greenhouses in many countries all over the world, a number of demonstration projects were implanted and the encouraging results lead to a continuous extension of the covered area and the application of new strategies (Ben Mohamed and Said 2008; Ben Mohamed 2015). Hence, the total area of the geothermally heated greenhouses in Tunisia reached 224 ha with more than 25 projects being located in the Kebili and Tozeur regions (Ben Mohamed 2015). Besides agriculture activities, the main utilization of categories is bathing, balneotherapy, tourism, washing, and animal husbandry (Ben Mohamed and Said 2008; Ben Mohamed 2015).

The intensive utilization of the salt-enriched geothermal low-renewable groundwater in irrigation led to a continuous degradation of the quality of the irrigated water and increasing risks of soil salinization and alkalinization of the oases lands. Agriculture activities in Chotts Basin are currently threatened by soil fertility loss and crops quality reduction (Besser et al. 2017).

\section{Sampling and analyses}

In the present study, 41 representative sites have been selected for the collection of water samples from the Chotts region, object of geochemical analysis, carried out in the Fertilizer and Phosphate Laboratory in the Tunisian Chemical Group of Gabes (GCT-Tunisia) and in the Integrated Laboratory of Water at the High Institute of Sciences and Technologies of Water of Gabes (Tunisia), using standard methods of volumetric titrations ( $\mathrm{HCl}$, EDTA), spectrometry, flame photometer, high-performance liquid chromatography and flame photometer.

Additionally, 21 samples were collected across the study area for isotopic analysis carried out in the Integrated Laboratory of Water at the High Institute of Sciences and Technologies of Water of Gabes (Tunisia) using Chromatographie IC "Mentrohm 850". Aeration during sampling was avoided by stopping the bottles quickly. The results are reported in $\delta$ notation according to Vienna Standard Mean Ocean Water (VSMOW), where $\delta=\left[\left(R_{\mathrm{S}} / R_{\mathrm{SMOW}}\right)-1\right] \times 1000 ; R_{\mathrm{S}}$ is related to either the ${ }^{18} \mathrm{O} /{ }^{16} \mathrm{O}$ or the ${ }^{2} \mathrm{H} /{ }^{1} \mathrm{H}$ ratio of the sample, and $R_{\mathrm{SMOW}}$ represents the ratio of ${ }^{18} \mathrm{O} /{ }^{16} \mathrm{O}$ or ${ }^{2} \mathrm{H} /{ }^{1} \mathrm{H}$ of the SMOW. Typical precisions are generally about $\pm 0.1 \%$ and both elements.

The interpretation of the obtained data was based on a number of graphic presentations of commonly used plots made by MATLAB Starter Application 2008 version, GIS 10.1, Aquachem 2014.2, and Grapher 11 software. Figure 2 outlines the main insights of the used approach in the current hydrogeological investigation. The historic data collection is combined with field surveys to construct a conceptual understanding of the study area's particularities. Groundwater analyses provide quantitative assessment of groundwater quality. With the integration of computer software and numerical platforms, the aggregation of spatial visualization of different physical and chemical parameters gives useful information for a critical evaluation of groundwater composition changes based on literature review of the common criteria and the most used indices.

\section{Results and discussion}

Thermal fluid composition can change along fluid migration pathways due to enhanced hosted rock-fluid interaction, boiling, leaching, mixing, cooling, mineral equilibrium, and a number of natural processes controlling groundwater quality.

\section{In-field measurements}

The measured temperatures, in field, range between a minimum of $27{ }^{\circ} \mathrm{C}$ for the Mazrâa Neji region and a maximum of $72{ }^{\circ} \mathrm{C}$ measured at different points in Kebili and Tozeur area (Mzarâa, Esteftimi, Taourgha, El Hamma, Mahacen, and Ceddada) (Fig. 3a). As shown in Fig. 3b, the variation of groundwater temperature with well depth shows two separated groups: the first illustrates a good correlation with increasing depth while the second did not show any significant correlation $T$-depth. The calculated geothermic gradient in the study area, based on CI analyzed samples, ranges from 1.2 to $4.13{ }^{\circ} \mathrm{C} / 100 \mathrm{~m}$ (Fig. 3c). Different regions 


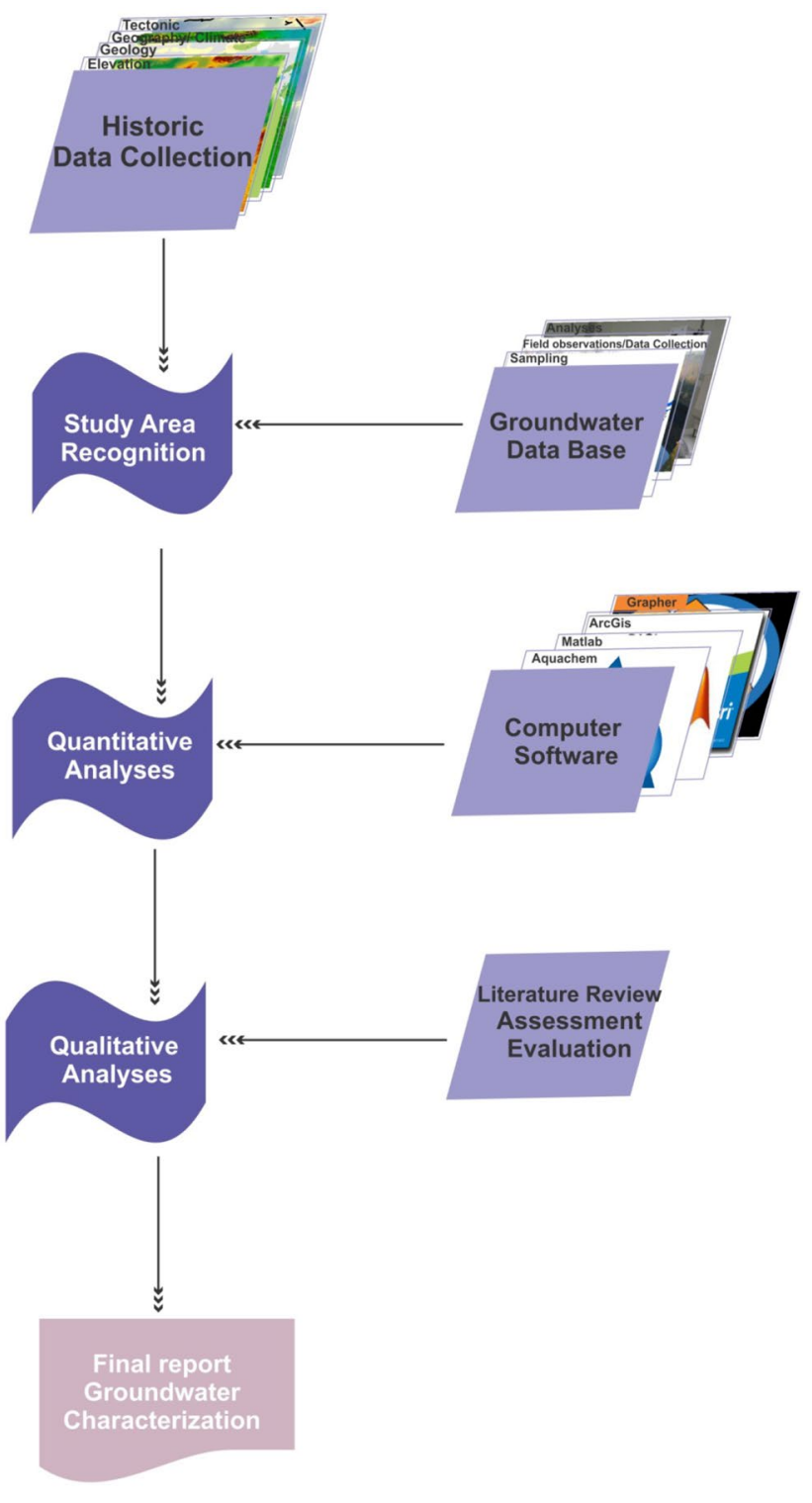

Fig. 2 Flow chart of the used methodology

show positive anomalies of geothermal gradient with respect to the Ben Dhia (1983) reference value. The $T$-depth profile, and similarly the thermal gradient variation, may be explained by the spatial distribution of resource lithology, basement heat flow, unconformities, fluid distribution, and the overpressure role related to the complexity of the architecture of the subterranean basin.

\section{Classification of thermal discharge water}

\section{$\mathrm{Na}^{+}-\mathrm{Mg}^{2+}-\mathrm{K}^{+}$ternary diagram}

The ternary diagram combines $\mathrm{Na}^{+}-\mathrm{Mg}^{2+}-\mathrm{K}^{+}$and $\mathrm{K}^{+}-\mathrm{Mg}^{2+}-\mathrm{Ca}^{2+}$ thermodynamics sub-systems. The combination of alkali and alkaline earth metal concentrations provides sub-system temperature estimation and assessment of water equilibrium (Giggenbach 1988). The solid line represents the full equilibrium state for both combined sub-systems. The classification of thermal water refers to three different fields: mature, partially equilibrated, and unstable fluids regard to $\mathrm{Na}-\mathrm{K}$ mineral equilibrium according to the following reactions (4), (5), and (6):

$\mathrm{K}$-Feldspar $+\mathrm{Na}^{+} \leftrightarrow \mathrm{Na}$-Feldspar $+\mathrm{K}^{+}$,

0.8 Muscovite +0.2 Clinochlore +5.4 Silica $+2 \mathrm{Na}^{+}$

$$
=2 \text { Albite }+0.8 \mathrm{~K} \text {-feldspar }+1.6 \text { water }+\mathrm{Mg}^{2+} \text {, }
$$

0.8 Muscovite + 0.2 Clinochlore + 5.4 Silica + $2 \mathrm{~K}^{+}$

$=2$ Albite +2 Albite $+2.8 \mathrm{~K}$-feldspar +1.6 water $+\mathrm{Mg}^{2+}$.

Figure $4 \mathrm{a}$ indicates that most of the water samples plot in the mature fully equilibrated field, close to the $\mathrm{Na}-\mathrm{K}$ axis, referring to an equilibrium temperature ranging between 120 and $140{ }^{\circ} \mathrm{C}$. Some samples fall in the partially equilibrated domain, suggesting mixing between different water bodies.

\section{$\mathrm{HCO}_{3}{ }^{-}-\mathrm{Cl}^{-}-\mathrm{SO}_{4}{ }^{2-}$ ternary diagram}

The ternary diagram helps to discern mature and unstable waters and to give crucial information about fluid mixing and geographic groupings, based on major anions concentrations (Giggenbach 1988, 1991; Giggenbach and Goguel 1989; Dolgorjav 2009). The position of the data point in this plot is obtained by first calculating the sum $\left(\sum_{\text {anions }}\right)$ of anions concentrations $(\mathrm{mg} / \mathrm{kg})$ of all species involved (7). The next step is to obtain the percent (\%) of every constituent using Eqs. (8, 9, 10):

$\sum_{\text {anions }}=\mathrm{CCl}^{-}+\mathrm{C}_{\mathrm{HCO}_{3}^{-}}+\mathrm{C}_{\mathrm{SO}_{4}^{2-}}$,

$\% \mathrm{Cl}^{-}=100_{\mathrm{C}_{\mathrm{Cl}}^{-}} / \sum_{\text {anions }}$

$\% \mathrm{SO}_{4}^{2-}=100 \mathrm{C}_{\mathrm{SO}_{4}^{2-}} / \sum_{\text {anions }}$

$\% \mathrm{HCO}_{3}^{-}=100 \mathrm{C}_{\mathrm{HCO}_{3}^{-}} / \sum_{\text {anions }}$.

Generally, chloride waters are found close to zones of upward flows while $\mathrm{SO}_{4}{ }^{2-}$-enriched waters are attributed mostly to high-altitude areas of the geothermal field. However, thermal fluid with $\mathrm{HCO}_{3}{ }^{-}$dominance is usually found 


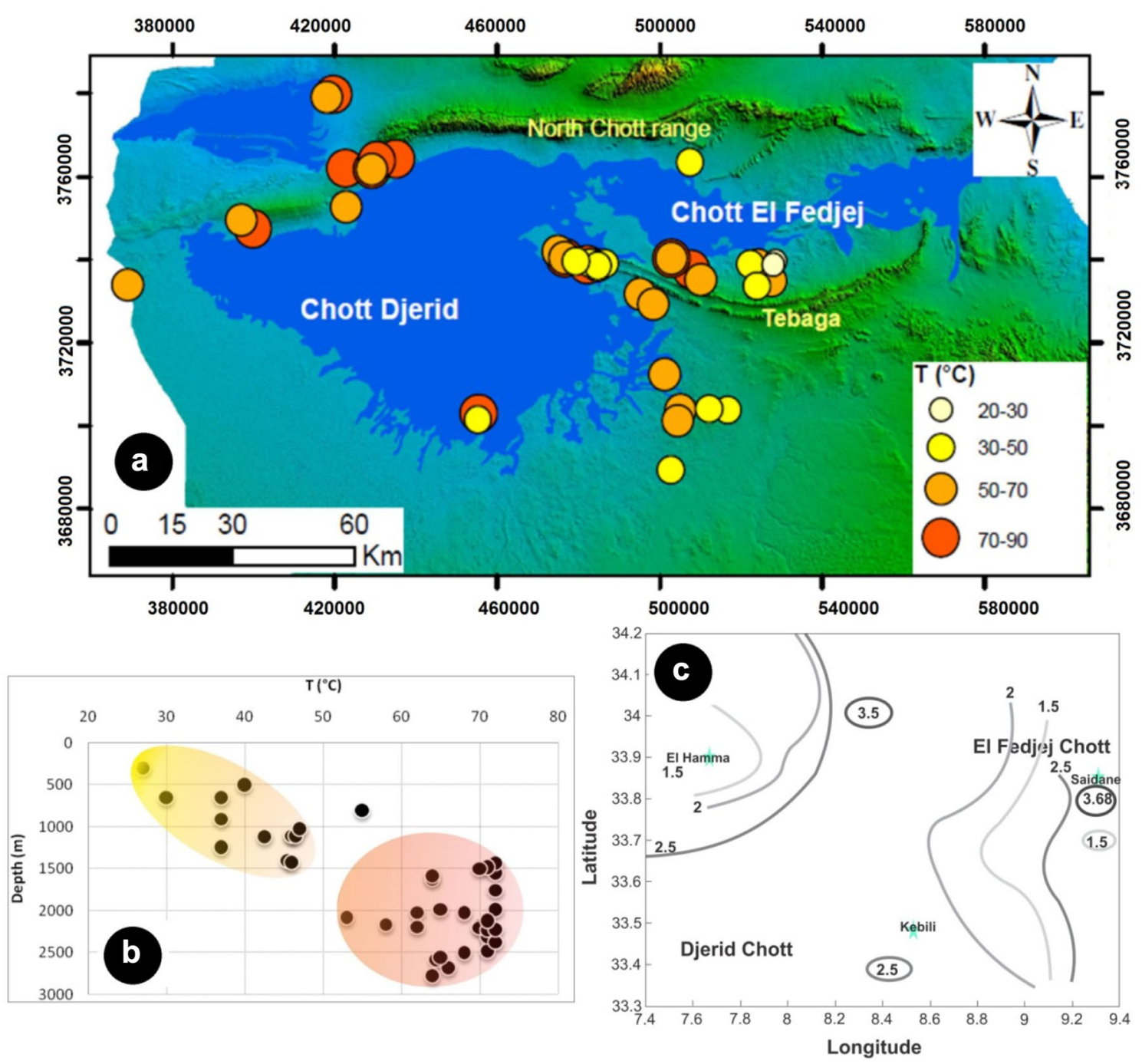

Fig. 3 a Temperature map; $\mathbf{b} T$-depth profile; $\mathbf{c}$ spatial distribution of the thermal gradient in the study area

at a certain distance from heat sources, as increasing bicarbonate concentrations are attributed to lower temperatures (Giggenbach 1991).

Figure $4 \mathrm{~b}$ illustrates two separated groups of the studied samples; the first refers to the majority of water points and shows an excess of $\mathrm{HCO}_{3}{ }^{-}$, while the second falls in the steam-heated waters. The scattered classification is probably due to mixing of the CI thermal water by with local cold shallow water of Complex Terminal CT aquifer. Correspondingly, according to Fig. 4c, the discharge waters from different sampled wells show an acid sulphate chloride "abundance of $\mathrm{Cl}^{-}$and $\mathrm{SO}_{4}{ }^{2-}$ " with a coefficient of variation of about 0.92 .

\section{$\mathrm{K}^{+}-\mathrm{Mg}^{2+}-\mathrm{Ca}^{2+}$ subsystem}

Thermal fluid $\mathrm{CO}_{2}$ partial pressure and equilibrium with respect to calcite can be evaluated using the $\mathrm{K}^{+}-\mathrm{Mg}^{2+}-\mathrm{Ca}^{2+}$ geo-indicator diagram obtained according to (11), (12), and (13) equations (Giggenbach 1988):

$L_{\mathrm{kc}}=\log \left(\mathrm{C}_{\mathrm{K}^{+}}^{2} / \mathrm{C}_{\mathrm{Ca}^{2+}}\right)$;

$L_{\mathrm{kc}}=\log p \mathrm{CO}_{2}+3$,

$L_{\mathrm{km}}=\log \left(\mathrm{C}_{\mathrm{K}^{+}}^{2} / \mathrm{C}_{\mathrm{Mg}^{2+}}\right)$.

The sampled waters plot below the equilibrium line (Fig. 5a) due to low high $\mathrm{K}^{2} / \mathrm{Mg}^{2+}$ and $\mathrm{K}^{2} / \mathrm{Ca}^{2+}$ ratios at $\mathrm{T}_{\mathrm{k}^{+}-\mathrm{Mg}^{2+}}$ from 60 to 80 , which corresponds to the average reservoir temperature in the study area. All facies are largely below the calcite formation line, which exhibits the dominance of $\mathrm{Na}^{+}$and $\mathrm{K}^{+}$over $\mathrm{Ca}^{2+}$ apparently related to the continental silicates reservoirs of the $\mathrm{CI}$ aquifer. 

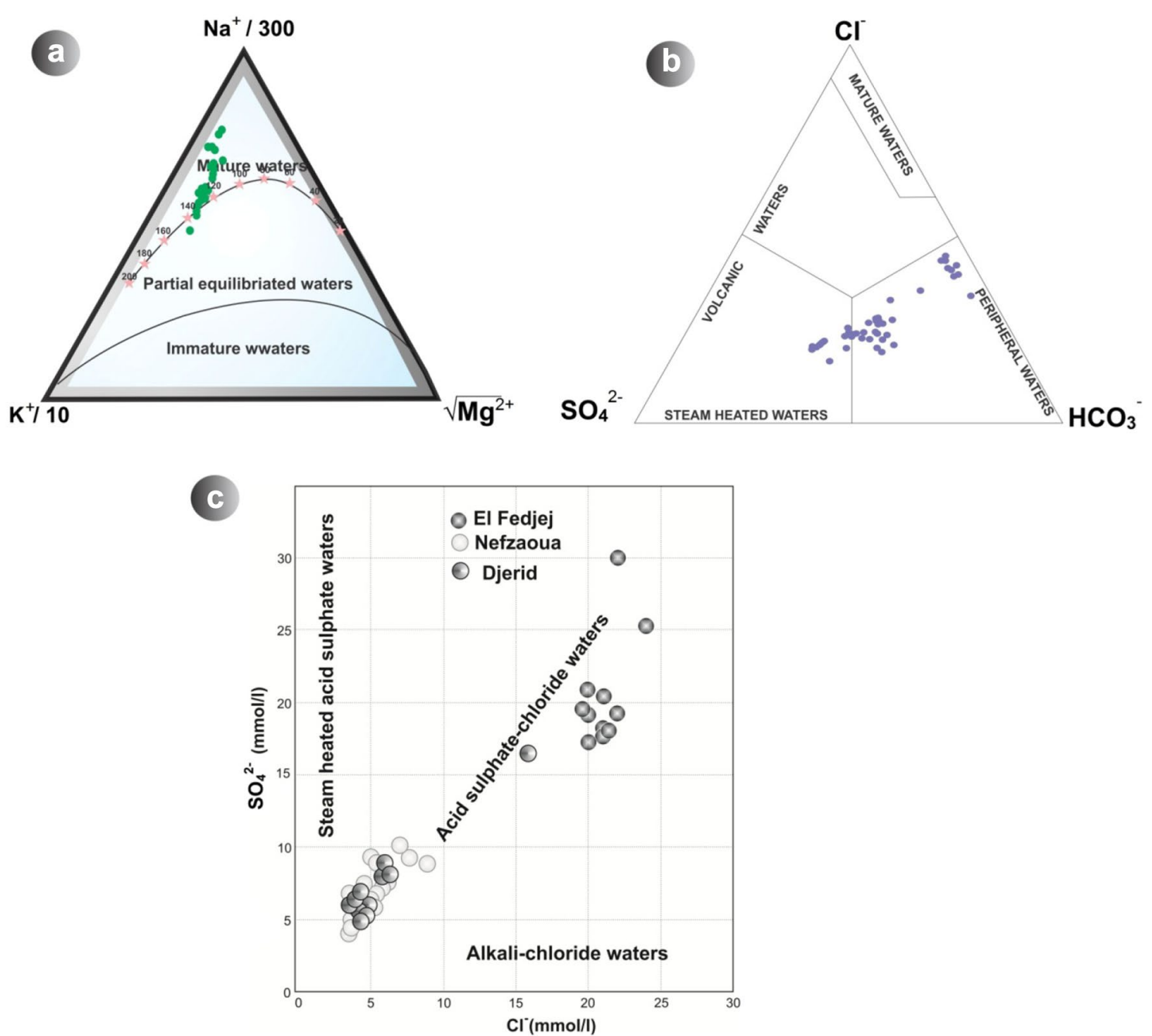

Fig. 4 a K ${ }^{+}-\mathrm{Mg}^{2+}-\mathrm{Na}^{+}$ternary diagram; $\mathbf{b ~ C l}{ }^{-}-\mathrm{SO}_{4}{ }^{2-}-\mathrm{HCO}_{3}{ }^{-}$ternary diagram; $\mathbf{c} \mathrm{Cl}^{-}-\mathrm{SO}_{4}{ }^{2-}$ correlation

\section{$\mathrm{K}^{+}-\mathrm{Na}^{+}-\mathrm{Mg}^{2+}-\mathrm{Ca}^{2+}$ subsystem}

This system combines the $\mathrm{K}^{+}-\mathrm{Na}^{+}-\mathrm{Mg}^{2+}$ and $\mathrm{K}^{+}-\mathrm{Mg}^{2+}-\mathrm{Ca}^{2+}$ thermodynamic subsystems and it is used to compare relative abundance of $\mathrm{Mg}^{2+}$ over $\mathrm{Ca}^{2+}$ (carbonates) and $\mathrm{Na}^{+}$and $\mathrm{K}^{+}$(alkali-silicates) (Giggenbach 1988). The solid line represents the full equilibrium to both sub-systems. Samples plotted below the curve refer to stable waters. Their chemical composition is not controlled by rock-water interactions but rather by water-mineral equilibrium (Ellis and Mahon 1977; Giggenbach 1995; Wishart 2015).

CI samples plot outermost to the equilibrium (Fig. 5b), which does not indicate any equilibrium between the hosted rocks and the groundwater chemical composition. Meanwhile, the studied samples are positioned slightly within the partial equilibrium field with a temperature ranging between 40 and $100{ }^{\circ} \mathrm{C}$. The geochemical composition of these immature waters is mainly controlled by water-rock interaction as all facies are plotted in the rock dissolution field. The analyzed samples show an apparent increase in $\mathrm{Na}^{+} / \mathrm{K}^{+}$and a decrease in $\mathrm{Mg}^{2+} / \mathrm{Ca}^{2+}$, which evidences silicate weathering and the poly-stage mixing of the groundwater.

\section{$\mathrm{Na}^{+} / \mathrm{K}^{+}$alteration system}

As shown in Fig. 5 c, the $\mathrm{Na}^{+} / \mathrm{K}^{+}$ratio shows a slight decreasing trend with increasing temperature. The position of all samples is far away from equilibration status of different minerals, except some points plot closely to albite-anduluria equilibrium. The inequilibrium in deep CI aquifer may be attributed to unstable waters governed by mixing and formations weathering processes in $\mathrm{Na}^{+}-\mathrm{K}^{+}$ content control. 

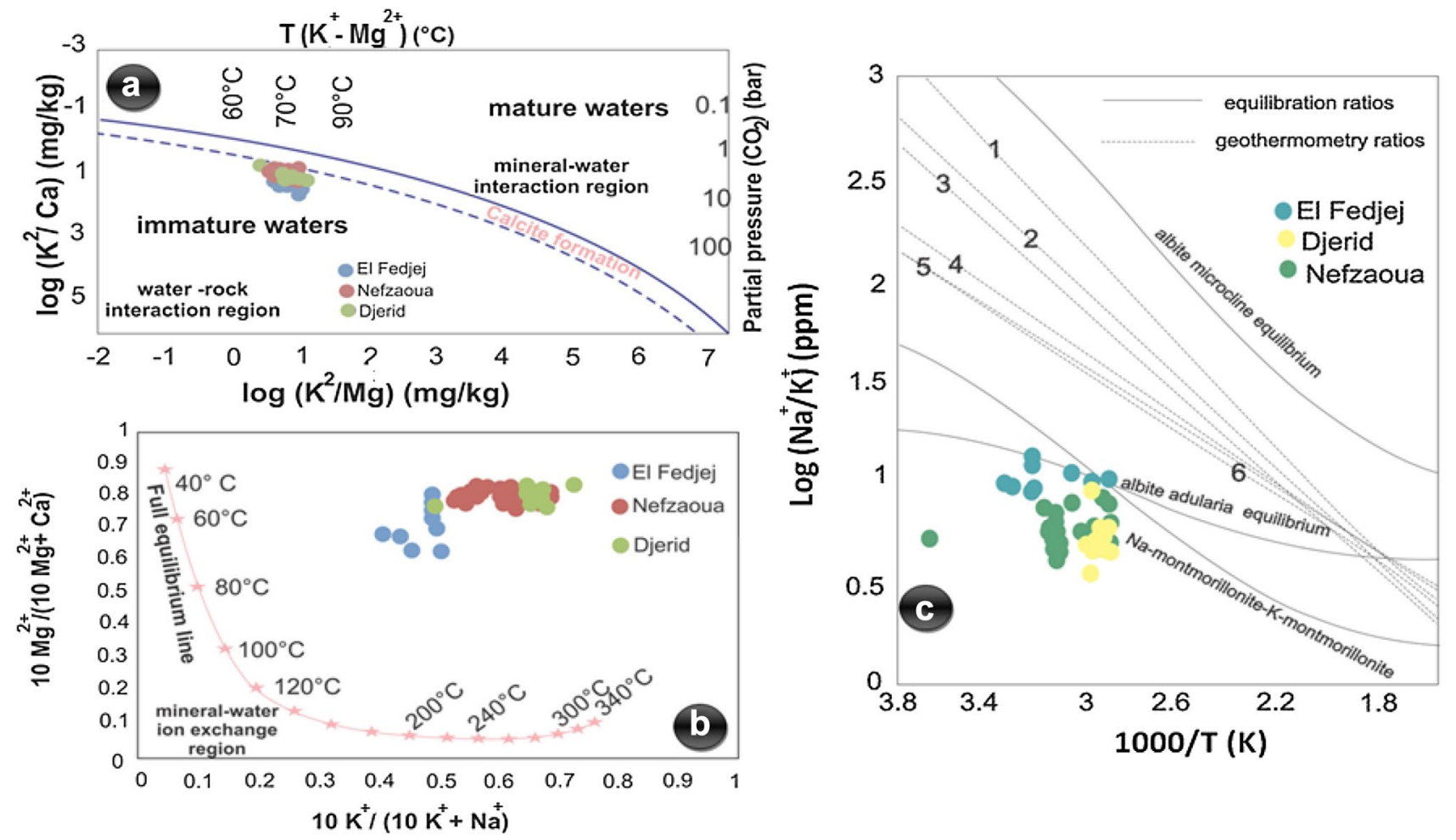

Fig. 5 a K ${ }^{+}-\mathrm{Mg}^{2+}-\mathrm{Ca}^{2+}$ subsystem; $\mathbf{b} \mathrm{K}^{+}-\mathrm{Na}^{+}-\mathrm{Mg}^{2+}-\mathrm{Ca}^{2+}$ subsystem; $\mathbf{c} \mathrm{Na}^{+} / \mathrm{K}^{+}$alteration system

\section{Maturity index}

Developed by Giggenbach (1988), it evaluates the degree of equilibrium rock-water in the reservoir, regardless to the origin of the thermal field. It is a linear combination of $\mathrm{Na}^{+}-\mathrm{K}^{+}$and $\mathrm{K}^{+}-\mathrm{Mg}^{2+}$ geothermometers and it is given by the following Eq. (14):

$$
\begin{aligned}
\mathrm{MI}= & 0.315 *\left(\log \left(\mathrm{K}^{2} / \mathrm{Mg}^{2+}\right)\right) *\left(\log \left(\mathrm{K}^{+} / \mathrm{Na}^{+}\right)\right), \\
& \text {concentrations in }(\mathrm{mg} / \mathrm{kg}) .
\end{aligned}
$$

For $\mathrm{MI}<2$, the waters are classified as immature waters, while for MI values ranging between 2 and 2.66, they used to be considered as partially mature. They are fully equilibrated for $\mathrm{MI}>2.66$.

Obviously, CI samples are definitely immature (Fig. 6). Thermal waters of CI aquifer score MI from -0.5 to -0.19 on maturity analyses classifying them distinctly immature. Samples of the contaminated area yield lower MI values while highest score is attributed to western side. As shown in Fig. 6, the low MI score is related to $\mathrm{Na}^{+}$deficiency, oversaturation with carbonates, and $\mathrm{Mg}^{2+}$ decrease, which is more pronounced in the El Fedjej field. The enrichment of water by $\mathrm{Na}^{+}$can be explained by a mixing with different water bodies and realizes as well the contribution of silicates formation in water chemistry.
Moreover, the larger the distance of the samples from the full equilibrium line, the less reliability gains application of cation geothermometer (Giggenbach 1988), taking into account the partial geothermometer results validation and interpretation.

\section{Geothermometry}

This is a temperature-dependent model for reservoir equilibrium estimation based on specific chemical reactions or isotope equilibrium fractionation (Pang 2001). The most important water geothermometers are silica (quartz and chalcedony), $\mathrm{Na}^{+}-\mathrm{K}^{+}, \mathrm{Na}^{+}-\mathrm{Ca}^{2+}-\mathrm{K}^{+}, \mathrm{K}^{+}-\mathrm{Na}^{+}-\mathrm{Mg}^{2+}-\mathrm{Ca}^{2+}$ correction, and $\mathrm{K}^{+}-\mathrm{Mg}^{2+}$ geothermometers (Arnorsson 1985).

- $\mathrm{Na}^{+}-\mathrm{K}^{+}$geothermometer $\mathrm{The} \mathrm{Na}^{+} / \mathrm{K}^{+}$ration decreases with increasing fluid temperature based on temperaturedependant cation exchange reaction between albite and K-feldspars (12):

$\mathrm{NaAlSi}_{3} \mathrm{O}_{8}+\mathrm{K}^{+}=\mathrm{KAlSi}_{3} \mathrm{O}_{8}+\mathrm{Na}^{+}$

(Albite) (Orthose)

The advantage of this geothermometer is that it is less affected by dilution or stream loss and it is unsuitable for waters with high or low concentrations of calcium ((log 
Fig. 6 Maturity index of CI samples

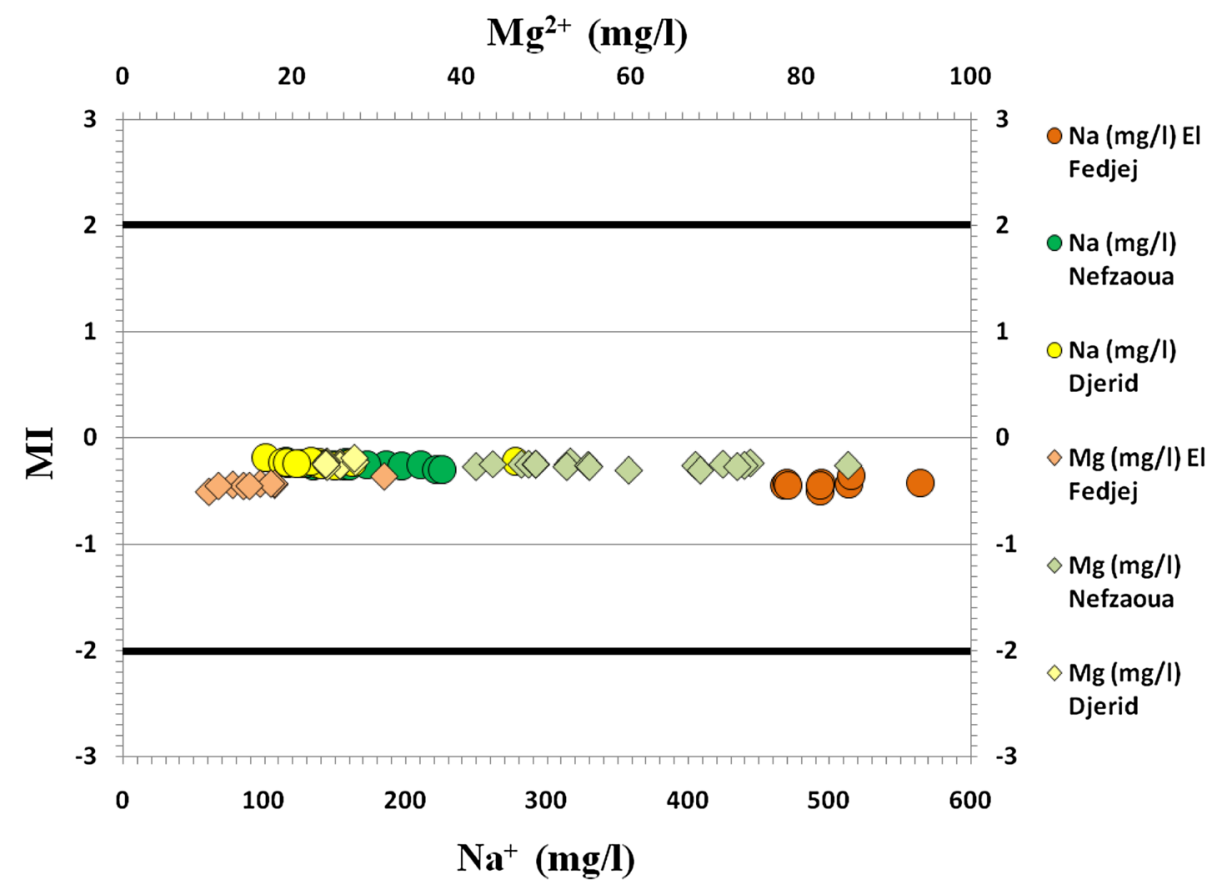

$\sqrt{\mathrm{C}_{\mathrm{Ca}^{2+}}} / \mathrm{C}_{\mathrm{Na}^{+}}$) +2.06 is negative) (Giggenbach 1988; Fournier and Potter 1997; Karingithi 2009). The temperature is obtained according to the following Eq. (16) (Arnorsson 1983):

$T=\left(\alpha /\left(\beta+\log \left(\mathrm{K}^{+}: \mathrm{Na}^{+}\right)\right)\right)-273.15$.

For the current study, $\alpha=1319 ; \beta=1.699$.

- $\mathrm{Na}^{+}-\mathrm{Ca}^{2+}-\mathrm{K}^{+}$geothermometer Established by Fournier and Truesdell (1973) to estimate reservoir temperature with high concentrations of calcium (Eqs. 17, 18, 19). It gives more reliable results in comparison with the $\mathrm{Na}-\mathrm{K}$ geothermometer for low-enthalpy geothermal waters (Fournier and Truesdell 1973; Karingithi 2009). It should be used if $\left(\log \left(\sqrt{\mathrm{C}_{\mathrm{Ca}^{2+}}} / \mathrm{C}_{\mathrm{Na}^{+}}\right)>0\right)$ and it is not applicable for acid waters nor for water systems showing particular (high or low) concentrations of an alkali:

$\left.T=1647 /\left(\left(\log \left(\mathrm{CNa}^{+} / \mathrm{CK}^{+}\right)\right) 1+\beta\left(\log \left(\sqrt{\mathrm{C}_{\mathrm{Ca}^{2+}}} / \mathrm{C}_{\mathrm{Na}^{+}}\right)\right)\right)\right)-273.15$,

$\beta=4 / 3$ for $\left.\sqrt{\mathrm{C}_{\mathrm{Ca}^{2+}}} / \mathrm{C}_{\mathrm{Na}^{+}}\right)>1$ and $T 4 / 3<100{ }^{\circ} \mathrm{C}$,

$\beta=1 / 3$ for $\left.\sqrt{\mathrm{C}_{\mathrm{Ca}^{2+}}} / \mathrm{C}_{\mathrm{Na}^{+}}\right)<1$ and $T 4 / 3>100{ }^{\circ} \mathrm{C}$.

- $\mathrm{K}^{+}-\mathrm{Na}^{+}-\mathrm{Mg}^{2+}-\mathrm{Ca}^{2+}$ geothermometer This is a modified version of the $\mathrm{K}^{+}-\mathrm{Na}^{+}-\mathrm{Ca}^{2+}$ geothermometer used to correct temperature estimations for solutions that contain high dissolved $\mathrm{Mg}^{2+}$ (20) (Fournier and Potter 1997; Karingithi 2009):
$R=\mathrm{Mg}^{2+} /\left(\mathrm{Mg}^{2+}+\mathrm{Ca}^{2+}+\mathrm{K}^{+}\right)$.

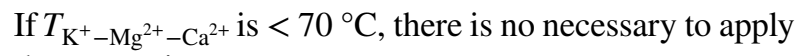
the correction;

If not If $R>50, T_{\mathrm{Mg}^{2+} \text { correction }}=\mathrm{T}_{\mathrm{K}^{+}-\mathrm{Na}^{+}-\mathrm{Ca}^{2+}}$;

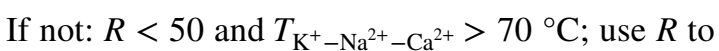
determine $\Delta T_{\mathrm{Mg}}^{2+}$ (Fournier 1977) and subtract $\Delta T_{\mathrm{Mg}}^{2+}$ from $T_{\mathrm{K}^{+}-\mathrm{Na}^{2+}-\mathrm{Ca}^{2+}}$ to get correct geothermometer temperatures.

- $\mathrm{K}^{+}-\mathrm{Mg}^{2+}$ geothermometer Developed by Giggenbach (1988), this geothermometer is applied to situations where there is no equilibrium of $\mathrm{Na}^{+}$and $\mathrm{Ca}^{2+}$ between the hosted rock and the thermal water. It is based on the chemical reaction that attains equilibrium at low temperature (Giggenbach 1988; Karingithi 2009) (21):

$T=\left(4410 /\left(14+\left(\log \left(\mathrm{K}^{2} / \mathrm{Mg}^{2+}\right)\right)\right)\right)-273.15$.

As presented in Fig. 7, the average temperature of the thermal waters from deep CI aquifer ranges between 58 and 83 when $\mathrm{K}^{+}-\mathrm{Mg}^{2+}$ geothermometers is applied. It spans between 28 and $292{ }^{\circ} \mathrm{C}$ for the $\mathrm{Na}^{+}-\mathrm{K}^{+}$geothermometer. The temperature of the water reservoir varies from 64 to 95 and 51 and 106, respectively, using $\mathrm{Na}^{+}-\mathrm{K}^{+}-\mathrm{Ca}^{2+}$ and $\mathrm{Mg}$-correction geothermometers. The highest temperature estimation may reflect the heat source of the thermal aquifer in deep levels. The discrepancies between different used geothermometers results may be attributed to variable intensity of equilibrium of different reactions. 


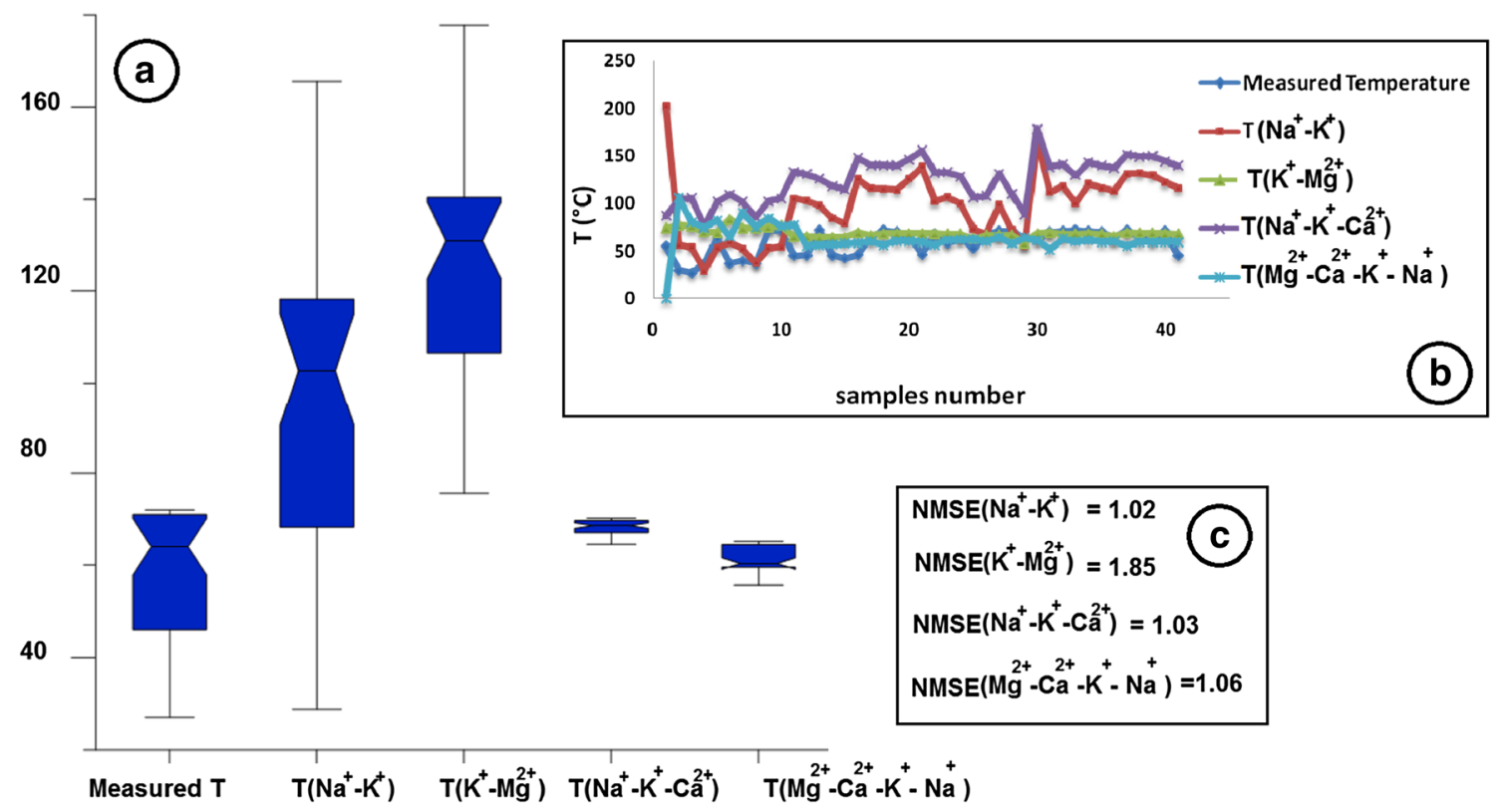

Fig. 7 a Cation geothermometers temperature estimations; $\mathbf{b}$ correlation $T_{\text {mes }}-T_{\text {cal }}$, $\mathbf{c}$ NMSE of $T_{\text {mes }}$

The application of different cation geothermometers for the estimation of CI thermal water temperature shows scattered results largely above the measured values. The $T_{\mathrm{Mg}}$ correction reveals the most restraint interval of values (Fig. 7a, b). However, the calibration of the different cation geothermometers used for the estimation of groundwater temperature is assessed using the normalized mean square error NMSE (22):

$$
\begin{aligned}
\text { NMSE }= & \left(\sqrt{ }(1 / N-1) \sum i=1\left(T_{\mathrm{mi}}-T_{\mathrm{gi}}\right)^{2} /\right. \\
& \left(\sqrt{ }(1 / N-1) \sum i=1\left(T_{\mathrm{mi}}-T_{\mathrm{moy}}^{2} .\right.\right.
\end{aligned}
$$

with $T_{\mathrm{mi}}=$ measured downhole temperature $\left({ }^{\circ} \mathrm{C}\right) ; T_{\mathrm{gi}}=$ calculated geothermometers temperature $\left({ }^{\circ} \mathrm{C}\right) ; T_{\text {moy }}=$ mean of $T_{\mathrm{mi}}\left({ }^{\circ} \mathrm{C}\right)$.

The obtained data highlight that the performance of the different geothermometers according to NMSE is in the following order: $\mathrm{Na}^{+}-\mathrm{K}^{+} ; \mathrm{Na}^{+}-\mathrm{K}^{+}-\mathrm{Ca}^{2+}$, $\mathrm{Na}^{+}-\mathrm{K}^{+}-\mathrm{Ca}^{2+}-\mathrm{Mg}^{2+}$ correction and $\mathrm{K}^{+}-\mathrm{Mg}^{2+}$ (Fig. $7 \mathrm{c}$ ).

\section{Aquifer chemistry}

\section{Hydrochemical facies}

The dynamic chemical behavior of groundwater reveals perpetual changes in fluid composition. As the hydrogeological investigation aims to ensure both water supplies in accordance with quality criteria for different uses, the assessment of groundwater chemistry, its spatial distribution related to tectonic architecture, and regional hydrogeological system constitutes a useful tool for identifying groundwater types and for assessing its evolution under natural conditions or in response to human perturbations.

The Durov diagram (1948) is an alternative of the Piper diagram and it utilizes two triangular diagrams connected into a square, adding total dissolved solids and $\mathrm{pH}$ of the water samples in the connecting rectangles. It is one of the most commonly used diagrams for better characterization of hydrochemical water types and identifying possible hydrochemical processes. It indicates the evolutionary trend of the hydrochemical facies. It displays a number of chemical processes (mixing, cation exchange, dissolution, etc.) affecting groundwater composition and controlling the evaluation of its quality by clustering waters revealing similar composition.

The hydrochemical parameters were plotted using a Durov diagram and according to the classification of Lloyd and Heathcotte (1985); the sampled CI waters illustrate separated groups (Fig. 8a). The majority of the data set is attributed to mixed zone with no dominant major anion or cation. A second group falls in $\mathrm{Cl}^{-}$dominant anion and $\mathrm{Na}^{+}$ dominant cation, indicating the dominance of reverse ion exchange. The remaining is governed by high $\mathrm{Na}^{+}, \mathrm{SO}_{4}{ }^{2-}$, and $\mathrm{Cl}^{-}$contents, indicating the importance of dissolution and mixing processes in groundwater quality control.

\section{D'Amore index}

The behavior of major chemical components in the CI aquifer is evaluated by the genetic diagram (D'Amore et al. 1983) considered reliable for better understanding of subterranean 
Fig. 8 a Durov diagram; b genetic diagram IRRG

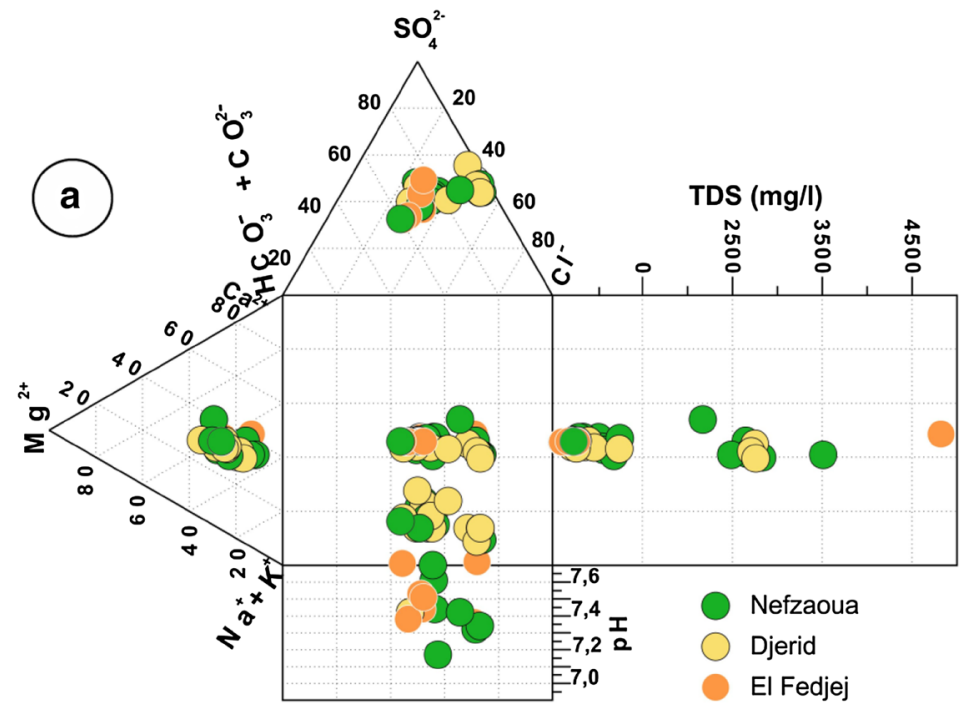

percentage (\%)

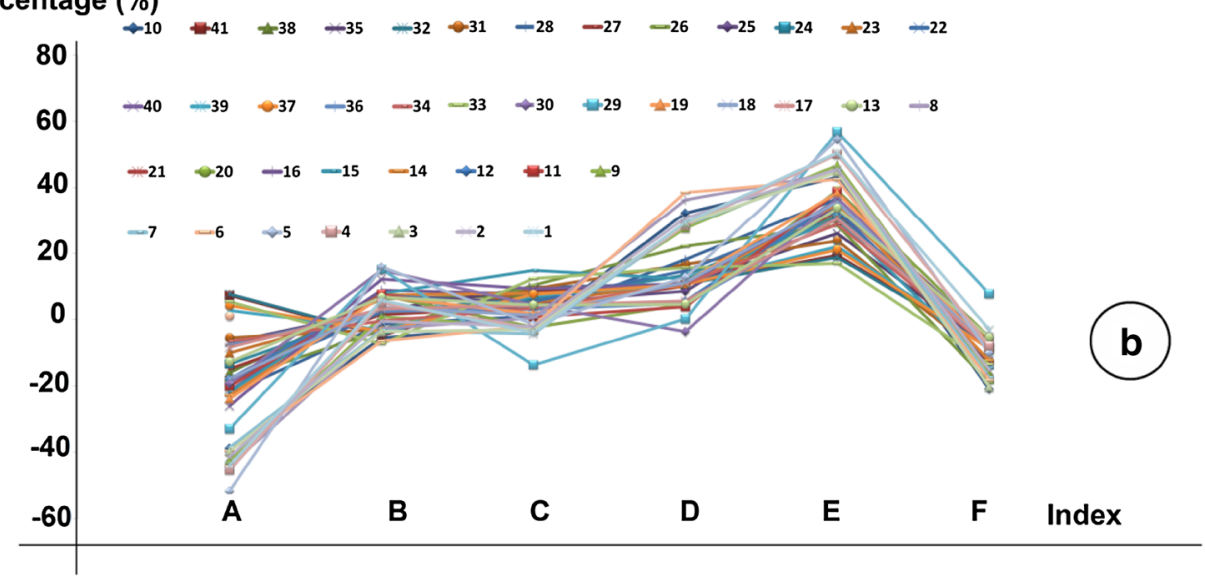

basin complex conditions and for clustering waters having similar chemical composition water groups (Milivojevic and Peric 1990).

As shown in Fig. 8b, and according to the IIRG method, the studied samples show a configuration similar to the standard diagram (1) (D'Amore et al. 1983), suggesting groundwater governed by chloride, sodium, and potassium contents referring to a deep circulation in sandy geologic formations. This description is in consistence with the CI aquifer lithology consisting of continental formations of the mega structure of the Continental Intercalaire. The deep circulation of the CI water is a conductive heat flow from deeper heat sources.

\section{Groundwater mixing}

The scatter plot of major element concentrations is shown in Fig. 9a. The plots of major element concentrations investigated the possible fluid source of thermal water from these correlations and according to isotopic cross plots
(Bayon et al. 2014). According to Fig. 9a, the variation in $\left(\mathrm{K}^{+}+\mathrm{Na}^{+}\right)$ratio is much less than those $\left(\mathrm{Mg}^{2+}+\mathrm{Ca}^{2+}\right)$. The analyzed samples show an ISL ranging from 5.09 to 33.15, expressed by two different groups illustrating the excess of alkaline earths over alkali metals, indicating the enhanced dissolution of frequent carbonate intercalations by CI thermal water, formations weathering, ion exchange process, and mixing influence.

Additionally, the $\mathrm{Cl}^{-}$did not show any significant correlation with temperature values, revealing the impact of rock-water interaction and mixing trend in thermal groundwater chemistry. In this connection, and according to meteoric genesis indices developed by Soltan (1998), the evaluation of water types and mixing processes can be assessed using Eq. (23):

$r_{2}=\left[\left(\mathrm{CNa}^{+}+\mathrm{CK}^{+}\right)-\mathrm{CCl}^{-}\right] / \mathrm{CSO}_{4}^{2-}$

where all concentrations are expressed in meq/l.

For $r_{2}<1$, the groundwater is attributed to deep meteoric water percolation, while for $r_{2}$ values greater than 2 , it 


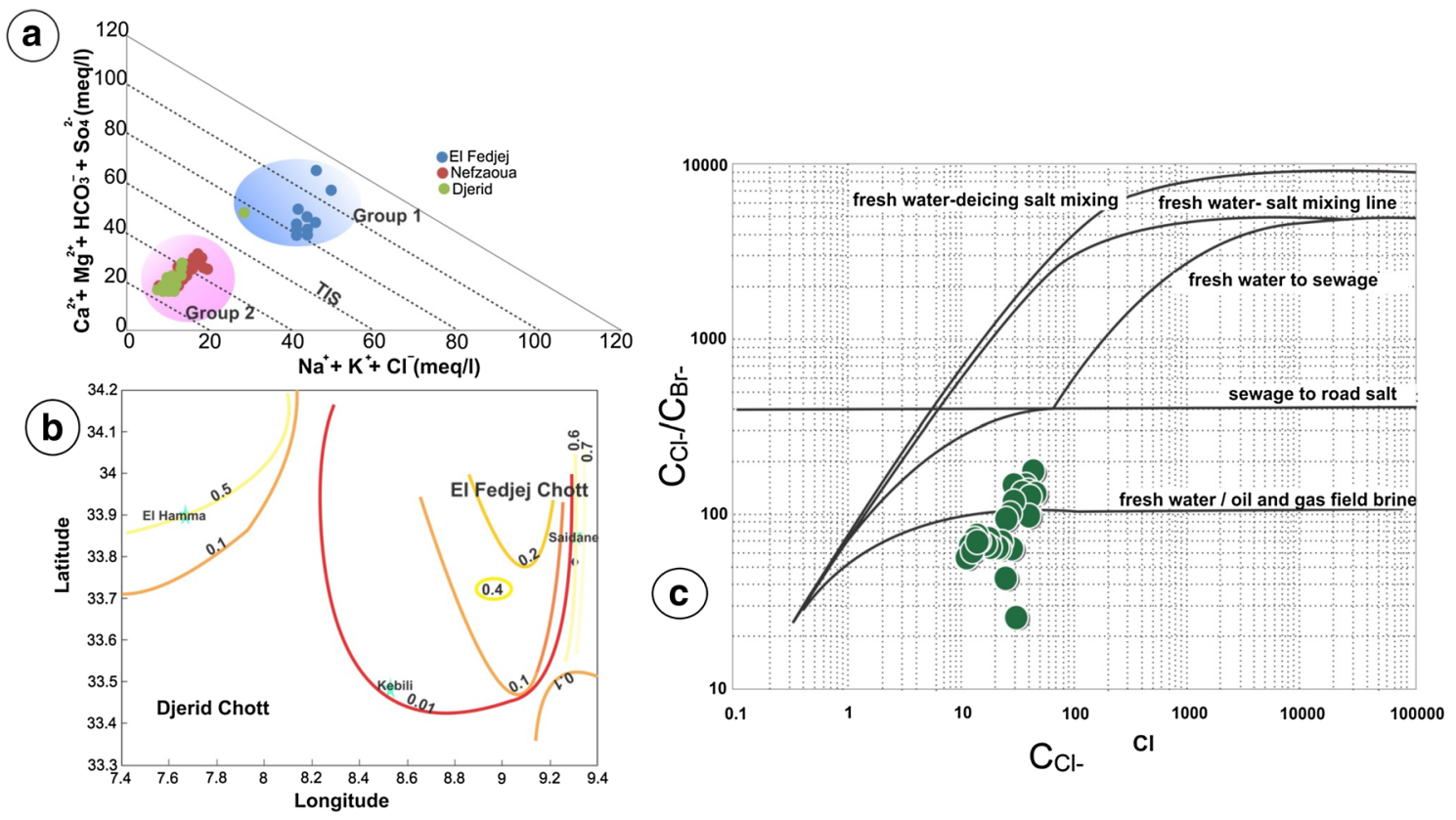

Fig. 9 a Major ions correlation; b mixing assessment based on ${ }^{18} \mathrm{O}$ values; $\mathbf{c} \mathrm{CCl}^{-}$vs. $\mathrm{CCl}^{-} / \mathrm{CBr}^{-}$plot

refers to a surface shallow meteoric water recharge. For the analyzed waters, $r_{2}$ vary between 0.05 and 0.51 in consistence with IRRG method results, revealing the impact of the dissolution, formations weathering, and mixing processes in CI groundwater composition.

Furthermore, and as shown in Fig. 9b, the correlation between $\mathrm{CCl}^{-}$and $\mathrm{CCl}^{-} / \mathrm{CBr}^{-}$proves the contribution of mixing process in $\mathrm{CI}$ water chemistry. All samples plot near the fresh water/oil and gas field brine. The scatter plot proves that the subsequent background changes in CI groundwater quality results from different mixing flows related not only to the hydrogeological system of the region but also from Chotts interference and deep reservoir intercommunication.

The scattered geochemical and isotopic data highlight that the CI groundwater composition appears to be influenced by mixing with different water bodies. To analyze this point thoroughly, different components could be used to discriminate the different waters, based on the following relationship used in the literature to determine the components of stream flow (Pinder and Jones 1969) (24):

$Q_{\mathrm{t}} / Q_{\mathrm{i}}=\left(C_{\mathrm{i}}-C_{\mathrm{c}}\right) /\left(C_{\mathrm{t}}-C_{\mathrm{c}}\right)$,

with: $C_{\mathrm{i}}=$ ion concentration in the sampled water; $C_{\mathrm{t}}=$ average ion concentration in the sampled water; $C_{\mathrm{c}}=$ ion concentration in the end member, not influenced water by mixing or not polluted water.

Based on the isotopic data of the studied samples, the groundwater composition seems to be largely influenced by the interference of chemically distinguishable water. The contribution of the initial CI water reveals a wide range of values spanning between 0.002 and 0.73 (Fig. 9c). It seems that according to the average isotopic composition of the sampled CI water and the average isotopic of rainfall in Nefta region in the study area, the studied samples exhibit a mixing of different groundwater bodies.

The CI chemical behavior constitutes a dynamic research field. The permanent background changes in the thermal water chemistry reveal the complexity of the multi-stage control of groundwater composition and result from the combination of both natural and anthropogenic factors in the studied area. In fact, in Chotts Basin, the CI thermal resources have for decades provided safe, permanent water resources less prone to contamination and inter-annual and season climate variability. It secures continuous freshwater resources although the scanty precipitations and the intermittent surface water often non available and inconvenient for consumption. Intense agricultural development that constitutes the key economic activity in the region is heading towards increasing water demand in spite of the critical status of water quality, which has placed the $\mathrm{CI}$ thermal resources at greater risk of contamination. Otherwise, the $\mathrm{CI}$ as a multi-layered aquifer system interconnected laterally and vertically with different water bearing strata of the regional hydrogeological system, the increasing pumping of the resources is supplied generally by a mixing of different aquifer levels.

The overdraft of these aquifers will increase risks of salt lake flow interference and as an ultimate stage of unbalance and anthropogenic perturbations; the water demand may be supplied by a mixing of different fluid reservoirs in the region (PR, WR, Chotts, etc.). This contamination will 
add another dimension to the current critical water quality degradation and its harmful environmental impact (Fig. 10). In fact, soil fertility depends on three principal factors: climate conditions, availability, and management of irrigation water (Askri et al. 2011). The use of highly mineralized saltenriched thermal CI water associated with high evapotranspiration, rare precipitations, lack of proper drainage system, and initially gypsoils lead to the formation of gypsum crust in the upper soil layers, soil degradation, densification, loss of soil fertility, and water logging. Soil salinization induced already a decrease in tree vigor and a significant reduction in the production of trees and date quality (Zidi 1997; Daddi Bouhoun et al. 2010) and it will induce abandoned oases, unsuitable soil for agriculture, reduction of shallow aquifer recharge, and deep aquifer dewatering. Southwestern Tunisia is likely facing a water shortage crisis, unprofitable agriculture activities associated with climate change, and drought conditions, unless reasonable, flexible, feasible, multi-disciplinary permanently modified strategies can be developed at regional or even local scales.

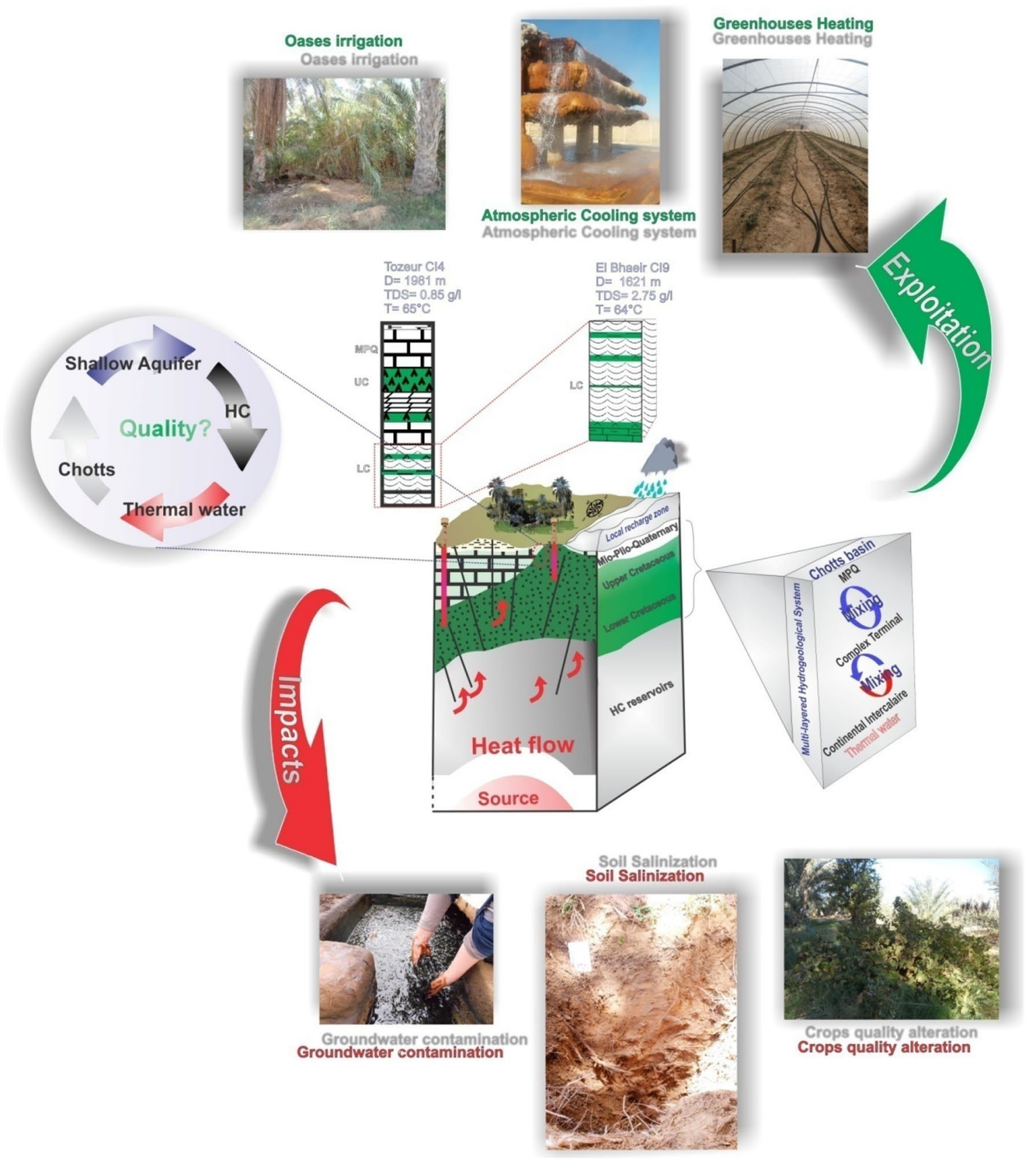

Fig. 10 Conceptual model of groundwater mixing in Chotts Basin 


\section{Conclusions}

A CI geothermal field in southern Tunisia is widely used essentially for irrigation activities, the most important economic activity in the region. This permanent exploitation alters initial quality and modifies natural flows. Thus, the potential and geochemical proprieties of geothermal waters for CI groundwater were studied in order to evaluate reservoir temperature and to assess groundwater chemistry and quality.

The obtained results indicate that $\mathrm{CI}$ geothermal waters are from different water types dominated by mixing water bodies and relative abundance of $\mathrm{SO}_{4}{ }^{2-}, \mathrm{Cl}^{-}$and $\mathrm{Na}^{+}$concentrations. The applied geothermometers owns to scattered results varying from 22 to $202{ }^{\circ} \mathrm{C}$. The $\mathrm{CI}$ thermal field is characterized by partially equilibrated waters, suggesting mixing with different water bodies. This is confirmed by a mixing ratio ranging from 27 to $98 \%$ based on isotopic data. The CI groundwater quality becomes modified with increasing overdraft. It seems influenced not only by the hydrogeological system but also by different fluid reservoirs in the region. Thus, the environmental impact of this mixing should be evaluated based on a quantitative approach depending on a detailed geophysical prospecting to a refined understanding of the thermal water recurrence patterns and its mixing with different reservoirs in Chotts Basin.

Acknowledgements The authors would like to thank the scientific committee of the International Symposium of Water Resources and Environmental Impact Assessment in North Africa (WREIANA), held in Gafsa (Tunisia), March, 24-26th, 2017, for the selection of this paper to be submitted for consideration in the volume consisting of selected papers based on oral and poster presentations from the scientific meeting. Special thanks go to all these experts for their help and critical advice during the symposium and for the insightful suggestions for improving the quality of the manuscript. Their gratitude extends to all the participants in the conference, invited speakers, presenters, and audience alike, for their comprehensive presentations and willingness to share their knowledge and experience.

\section{Compliance with ethical standards}

Conflict of interest The present paper is an original work and all the authors declare that they have no conflicts of interest.

Open Access This article is distributed under the terms of the Creative Commons Attribution 4.0 International License (http://creativeco mmons.org/licenses/by/4.0/), which permits unrestricted use, distribution, and reproduction in any medium, provided you give appropriate credit to the original author(s) and the source, provide a link to the Creative Commons license, and indicate if changes were made.

\section{References}

Arnorsson S (1983) Chemical equilibria in Icelandic geothermal systems: implications for chemical geothermometry in investigations. Geothermics 12:119-128
Arnorsson S (1985) The use of mixing models and chemical geothermometers for estimating underground temperatures in geothermal systems. J Volcanol Geotherm Res 23:209-335

Arnorsson S, D’Amore F, Gerardo-Abaya J (2000) Isotopic and geochemical techniques in geothermal exploration, development and use: sampling methods, data handling, interpretation. International Atomic Energy Agency Publication, Vienna. ISBN 92-0-101600-X

Askri B, Bouhlila R, Job JO (2011) A conceptual hydrologic model for studies of salinisation in Tunisian oases. Int J Water Resourc Arid Environ 1(6):428-439

Bayon FB, Tolentino BS, Barcelona B, Maneja FC, Salapare NC, Poblete JRB (2014) Integrated resource assessment and geothermal reservoir modelling from surface exploration (Preliminary) of Maricaban Island Geothermal Prospect. Prepared by FEDS Energy Resources and Development Services Inc. for DOEREMB. Internal Report, Taguig

Ben Brahim F, Jalila Makni J, Bouri S (2013) Properties of geothermal resources in Kebilli region, southwestern Tunisia. Environ Earth Sci 69:885-897

Ben Dhia H (1983) Les provinces géothermiuques de la Tunisie méridionale. Thèse de Doctorat Es-sciences naturelles. Univ. Bordeau I. 196 et 6 annexes

Ben Mohamed M (2015) Geothermal energy development: the Tunisian experience. In: Proceedings world geothermal congress, Melbourne, Australia

Ben Mohamed M, Said M (2008) Geothermal energy development in Tunisia: present status and future outlook. In: Proceedings 30th anniversary workshop, Reykjavik, Iceland

Besser H, Mokadem N, Redhaouania B, Rhimi N, Khelifi F, Ayadi Y, Omar Z, Bouajila A, Hamed Y (2017) GIS-based model evaluation of groundwater quality and estimation of soil salinization and land degradation risks in arid Mediterranean site (SW Tunisia). Arab J Geosci 10:350. https://doi.org/10.1007/s12517-017-3148-0

Bouaziz S, Barrier E, Soussi M, Turki MM, Zouari H (2002) Tectonic evolution of the northern African margin in Tunisia from paleostress data and sedimentary record. Tectonophysics 357:227-253

Boyce P, Fitzsimmons DP (2003) Open loop geothermal well systems on long island. New York. In: The 10th conference on geology of long island and metropolitan New York

Can I (2002) A new improved $\mathrm{Na} / \mathrm{K}$ geothermometer by artificial neural networks. Geothermics 31:751-760

Commissariat Régional du développement agricole CRDA (2010) Rapport interne

Commissariat Régional du développement agricole CRDA (2015) Rapport interne

D'Amore F, Scandiffiot G, Panichi C (1983) Some observations on the chemical classification of ground waters. Geothermics 12:141-148

Daddi Bouhoun M, Marlet S, Brinis L, Saker ML, Rabier J, Côte M (2010) A survey of the combined effects of waterlogging and salinity on fruit yield in the date palm groves of the Wargla Basin, Algeria. Revue Fruits 6:11-24

De Martonne E (1926) Aréisme et indice artidite. Comptes Rendus de L'Acad Sci Paris 182:1395-1398

Deon F, Förster HJ, Brehme M, Wiegand B, Scheytt T, Moeck I, Jaya MS, Putriatni DJ (2015) Geochemical/hydrochemical evaluation of the geothermal potential of the Lamongan volcanic field (Eastern Java, Indonesia). Geotherm Energy 3-20. https://doi. org/10.1186/s40517-015-0040-6

Dolgorjav O (2009) Geochemical characterization of thermal fluids from the Khangay Area, Central Mongolia. Geothermal Training Programme Orkustofnun, Grensásvegur 9, IS-108 Reykjavík, Iceland 10 
Dotsika E, Leontiadis I, Poutoukis D, Cioni R, Raco B (2006) Fluid geochemistry of the Chios geothermal area, Chios Island, Greece. J Volcanol Geotherm Res 154(3-4):237-250

Durov SA (1948) Classification des eaux naturelles et la représentation graphique de leur composition. Doklady Akad Nauk SSSRt 59(1):87-90

Edmunds WM, Shand P, Guendouz AH, Moulla AS, Mamou A, Zouari K (1997) Recharge characteristics and groundwater quality of the Grand Erg Oriental basin. Tech Rep. IAEA, Vienna

Ellis AJ, Mahon WAJ (1977) Chemistry and geothermal systems. Academic Press, New York

ERESS (1972) Water resources study in Septentrional Sahara, vol 7. UNESCO, Paris

Ferchichi A (1996) Etude climatique en Tunisie présahrienne. MEDIT $3(8): 46-53$

Fournier RO (1977) Chemical geothermometers and mixing models for geothermal systems. Geothermics 5(1/4):41-50

Fournier RO, Potter RWII (1997) Magnesium correction to Na-K$\mathrm{Ca}$ chemical geothermometer. Geochem Cosmochim Acta 43:1543-1550

Fournier RO, Truesdell AH (1973) An empirical Na-K-Ca geothermometer for natural waters. Geochim Cosmochim Acta $37: 1255-1275$

Fourré E, Jean-Baptiste P, Dapoigny A, Lavielle B, Smith T, Thomas B, Vinsot A (2011) Dissolved helium distribution in the Oxfordian and Dogger deep aquifers of the meuse/haute-marne area. Phys Chem Earth 36(17-18):1511-1520

Giggenbach WF (1988) Geothermal solute equilibria. Derivation of $\mathrm{Na}-\mathrm{K}-\mathrm{Mg}-\mathrm{Ca}$ geoindicators. Geochim Cosmochim Acta 52:2749-2765

Giggenbach WF (1991) Chemical techniques in geothermal exploration. In: D'Amore F (ed) Applications of geochemistry in geothermal reservoir development. UNITAR/UNDP, Rome, pp 119-142

Giggenbach WF (1995) Geochemical exploration of a 'difficult' geothermal system, Paraso, Vella Lavella, Solomon Islands. In: Proceedings of the world geothermal congress 1995, Florence, Italy, vol 2, pp 995-1000

Giggenbach WF, Goguel RL (1989) Collection and analysis of geothermal and volcanic water and gas discharges. Report No. CD 2401. Department of Scientific and Industrial Research. Chemistry Division. Petone, New Zealand

Hamed Y, Ahmadi R, Hadji R, Mokadem N, Ben Dhia H, Ali W (2013) Groundwater evolution of the continental Intercalaire aquifer of southern Tunisia and a part of southern Algeria: use of geochemical and isotopic indicators. Desalin Water Treat 52(10-12):1990-1996

Hamed Y, Ahmadi R, Demdoum A, BouriS Gargouri I, Ben Dhia H, Al-Gamal S, Laouar R, Choura A (2014) Use of geochemical, isotopic, and age tracer data to develop models of groundwater flow: a case study of Gafsa mining basin-southern Tunisia. J Afr Earth Sci 100:418-436

Hlaeim A (1999) Halokinesis and structural evolution of the major features in Eastern and Southern Tunisian Atlas. Tectonophysics 306:79-95

Karingithi CW (2009) Chemical geothermometers for geothermal exploration. In: Proceedings short course on exploration of geothermal resources, Lake Naivasha, Kenya

Lazzez M, Zouaghi T, Ben Youssef M (2008) Austrian phase on the northern African margin inferred from sequence stratigraphy and sedimentary records in southern Tunisia (Chotts and Djeffara areas). CR Geosci 340:543-552

Lloyd WJ, Heathcotte JA (1985) Natural inorganic hydrochemistry in relation to groundwater. Clarendon Press, Oxford
Makni J, Ben Brahim F, Hassine S, Bouri S, Ben Dhia H (2012) Hydrogeological and mixing process of waters in deep aquifers in arid regions: south east Tunisia. Arab J Geosci 6:2673-2683. https:// doi.org/10.1007/s12517-011-0510-5

Milivojević M, Perić M (1990) Studija: geotermalna potencijalnost teritorije SR Srbije van teritorija SAP. Rudarsko-geološki fakultet, Beograd

Mokadem N, Demdoum A, Hamed Y, Bouri S, Hadji R, Boyce A, Laouar R, Sâad A (2016) Hydrogeochemical and stable isotope data of groundwater of a multi-aquifer system: northern Gafsa basin- Central Tunisia. J Afr Earth Sci 114:174-191

Pang ZH (2001) Isotope and chemical geothermometry and its application. Sci China Serie E Technol Sci 44(1):16-20

Penman HL (1948) Natural evaporation from open water, bare soil andgrass. In: Proceedings of the Royal Society of London. Series A, Mathematical and Physical Sciences, vol 193, No. 1032. pp $120-145$

Pinder GF, Jones JF (1969) Determination of the ground-water component of peak discharge from the chemistry of total runoff. Water Resour Res 5(2):8p

Porowski A, Dowgiałło J (2009) Application of selected geothermometers to exploration of low-enthalpy thermal water: the Sudetic Geothermal Region in Poland. Environ Geol 58:1629-1638

Reed MH, Spycher N (1984) Calculation of $\mathrm{pH}$ and mineral equilibria and reaction processes in hydrothermal waters with application to geothermometry and studies of boiling and dilution. Geochim Cosmochim Acta 48:1479-1492

Soltan ME (1998) Characterization, classification and evaluation of some round water samples in upper Egypt. J Chemosphere $37: 735-745$

Stefansson V (1985) The Nesjavellir high temperature geothermal field in Iceland. In: Proceedings of the 10th workshop on geothermal reservoir engineering, Stanford University report, SGP-TR-84, pp 23-30

Thornthwaite CW (1948) An approach toward a rational classification of climate. Geogr Rev 38(1):55-94

United Nations Educational, Scientific and Cultural Organization (UNESCO) (1979) Map of the world distribution of arid regions: Map at scale 1:25,000,000 with explanatory note. MAB Technical Notes 7, UNESCO, Paris

Vimmerstedt LJ (1998) Opportunities for small geothermal projects: rural power for Latin America, the Caribbean and the Philippines. Natural Renewable Energy Laboratory, Colorado, USA

Wishart DBN (2015) Comparison of silica and cation geothermometers of bath hot springs, Jamaica WI. In: Proceedings world geothermal congress Melbourne, Australia

Ben Dhia H, Bouri S (1995) Overview of geothermal activities in Tunisia. Ecole Nationale d'Ingenieurs de Sfax, Tunisia

Zargouni F (1985) Tectonique de l'Atlas Méridional de Tunisie: évolution géométrique et cinématique des structures en zone de cisaillement. Rev Sci Terre 3:304p

Zidi C (1997) Régime de la nappe superficielle et incidences sur la salure des sols et la production des dattes dans l'oasis de Tarfaya (Kébili). ES 297, Soils directorate, Ministry of Agriculture, Tunisia

Zouaghi T, Guellala R, Lazzez M, Bédir M, Ben Youssef M, Inoubli MH, Zargouni F (2011) The chotts fold belt of southern Tunisia, North Afrian margin, structural pattern, evolution and regional geodynamic implications. In: Schattner U (ed) New frontiers in tectonic research-At the midst of plate convergence. InTech. ISBN 978-953-307-594-5 